\title{
ТЕМАТИЧНИЙ АНАЛІЗ ІСТОРІОГРАФІЧНИХ ПРАЦЬ ПРО ЧИН СВ. ВАСИЛІЯ ВЕЛИКОГО (за матеріалами наукових видань української діаспори другої половини ХХ ст.)
}

\author{
Мар'ян Лозинський \\ Львівський національний університет імені Івана Франка, \\ вул. Генерала Чупринки, 49, 79044, Львів, Украӥна, \\ e-mail: m lozynskyj@lnu.edu.ua
}

В статті здійснено тематичний аналіз досліджень, присвячених історіографії про Чин св. Василія Великого Української греко-католицької Церкви, книговидавнича традиція якого розпочалася ще в XVII ст. і продовжується до сьогодні. Видання отців василіян охоплюють 3 початку XX ст. широкий спектр видань, серед яких - періодика (зокрема, «Записки ЧСВВ») і наукова література.

Автор як дослідник цих типів видань привертає увагу до публікацій в науковій періодиці, зокрема, в журналі «Український Історик».

Ключові слова: видання, журнал, «Український Історик», ЧСВВ, дослідження, монографія, рецензія.

В історії українського книговидання у XX ст. одну з провідних ролей зіграв Василіянський Чин св. Йосафата УГКЦ (далі - ЧСВВ). Метою нашої статті є дослідження історіографії про Чин св. Василія Великого на сторінках наукових видань світського характеру, які виходили друком в академічному середовищі діаспори в 50-90 роках XX ст.

Спочатку про публікації органу Українського Історичного Товариства - періодичного журналу «Український Історик». Вже в першому річнику (1963 р.) тут вміщена стаття Іринея Назарка про василіянський науковий осередок у Римі [1]. В ній автор стисло інформує про наукові досягнення в царині історико-церковних досліджень та публікацій джерел грона істориків-василіян, які після Другої світової війни через відомі політичні обставини опинилися в Римі і згуртувалися 3 метою історико-дослідницької та видавничої праці. Це, зокрема, такі відомі вчені - ченці ЧСВВ як Теодосій Тит Галущинський, Гліб Григорій Кінах, Атанасій Григорій Великий, Михайло Мирослав Ваврик, Мелетій Михайло Войнар, Іриней Іван Назарко, Ісидор Іван Патрило та ін. Їхніми зусиллями в Римі було не тільки відновлено випуск довоєнних львівських «Записок ЧСВВ», які тепер стали виходити як 2-а секція цього видання, але й засновано дві нові секції: Секція 1. Праці (окремі індивідуальні монографії і дослідження); Секція 3. Документи римських архівів. Оскільки віднов-

(C) Лозинський М., 2018 
лені «Записки ЧСВВ» стали виходити поза Україною, їх офіційною мовою стала латинь 3 допущенням інших європейських мов, хоча більшість публікацій були все ж українською мовою. Автор статті перелічив випуски всіх трьох секцій «Записок ЧCBB» /Analecta OSBM, які побачили світ до 1964 року, і задоволено відзначив, що багато наукових і суто фахових журналів висловилися про ці видання «з найвищим признанням» $[2, \mathrm{c.} 20]$.

«Український Історик» часто відгукувався на видання отців василіян. Зокрема в 6-му випуску за 1969 рік редакція журналу вмістила рецензію на 5 і 6 томи (секція 2) «Записок ЧСВВ», які вийшли в 1967 р. Ї̈̈ автор, який підписався криптонімом Р.Д., «не має сумніву, що Записки сьогодні являються одним з найповажніших теологічно-історичних українських періодиків» [3, с.166]. Аналізуючи 5-й том журналу, рецензент назвав вельми позитивним те, що в ньому редакція опублікувала матеріали, які були готові до друку вже в 1939 р., але через вибух війни не побачили виходу в світ. Це праці І. Филипчака і Р. Луканя «Окружна Головна школа в Лаврові: 1788-1911», В. Січинського «Архітектура Лаврова» та «Історія українського граверства XVI-XVIII ст.», Т. Коструби «Василіанські монастирі в Белзі», Г. Кінаха «Переписка О. Духновича з василіанами» та Р. Луканя «Список книг видавництва ЧСВВ у Жовкві». Відгукуючись на 6-й том «Записок ЧСВВ», присвячений 100-літньому ювілею канонізації св. Йосафата Кунцевича, автор рецензії відмітив поміщені в ньому дослідження А. Великого, І. Патрила, І. Назарка, М. Войнара, М. Ваврика, М. Соловія і Ю. Герича, які розглядають різні аспекти життя і діяльності св. священномуч. Йосафата. Недоліком видання рецензент назвав те, що «в ювілейному збірнику не подано ювілейної літератури про Йосафата, діяльність якого в працях православних істориків української церкви висвітлена 3 іншого боку, як в українській католицькій історіографії» [4, с.166-167].

Оцінюючи в цілому позитивно рецензовані томи «Записок ЧСВВ», автор все ж зробив зауваження, що на їх сторінках практично відсутні публікації світських істориків. Зосереджуючись виключно на історико-церковній та богословській тематиці, а також на історії Української Католицької Церкви та її визначних діячах, редакція, на думку рецензента, «дуже звужує історичну тематику» [5, с.167].

Помітним відгуком на чергове василіянське видання, що з'явився в «Українському Історику», була рецензія Юрія Гаєцького, професора Чикагзького університету на археографічну працю о. Атанасія Григорія Великого (ЧСВВ) «Документи Берестейської унії та її творців (1590-1600)» [6, с.135-146]. У вступному слові до рецензії Ю. Гаєцький відзначив, що з усіх 43-х томів різних документів з історії Української Церкви та українсько-римських церковних відносин, які о. А. Великий зібрав, опрацював і видав до 1970 року, його збірник матеріалів Берестейської унії заслуговує на особливу увагу. Адже видання цього тому було справою нелегкою, бо воно вимагало «багато праці, терпеливости та грунтовної наукової підготовки, щоб належно зібрати, проаналізувати та пояснити всі документи, що стосуються церковного життя українців та білорусинів між 1590-1960 роками» [7, с.135]. Далі рецензент детально викладає зміст праці, її структуру і методологію. Він, зокрема, відмітив, що значна частина опублікованих у ній документів (їх загальна кількість становила 357 позицій), - це папські листи, були і бреве (короткі письмові послання папи). Серед них також багато письмових розпоряджень римських урядових установ і донесень папських нунціїв. Далі йдуть королівські постанови, синодальні послання україн- 
сько-білоруської ієрархії, листи митрополитів, єпископів і навіть поодиноких шляхтичів та простих вірних. Особливо цінним у рецензованій праці, на думку Ю. Гаєцького, є те, що упорядник і видавець включив до неї також документи противників унії, зокрема князя Василя-Констянтина Острозького, Константинопольського патріархату та Львівського Ставропігійного братства. Беручи це до уваги, рецензент наголосив, що зібраний і виданий о. А. Великим матеріал буде корисним для всіх, хто цікавиться не тільки церковним минулим України й Білорусі, але й історією цілої Східної Свропи [8, с.136].

Наступним відгуком на василіянське видання, беручи до уваги хронологію видання «Українського Історика», була рецензія о. І. Назарка (ЧСВВ) на 1-й том праці А. Пекаря «Нариси історії Церкви Закарпаття» [9, с.128-130]. Оскільки про неї вже було сказано вище, то переходимо до аналізу іншої публікації на тему василіянської історіографії, яку оприлюднив на своїх сторінках «Український Історик». Це розгорнута рецензія згаданого А. Пекаря на другу частину монографії о. М. Соловія «Мелетій Смотрицький як письменник» [10].

Отож, рецензент назвав працю історика ЧСВВ «монументальною монографією», в якій автор «блиснув кропіткою аналізою писань конроверсійного українського владики поберестейських часів». Після стислого викладу змісту і структури роботи о. А. Пекар ствердив, що на основі багатьох джерел, часто маловідомих, а також свідчень різних дослідників о. М. Соловій дійшов слушного висновку про оригінальність і монументальність постаті М. Смотрицького. Рецензент цитує слова василіянського історика, які майже афористично характеризують феномен видатного українського вченого-філолога, церковного діяча, богослова й письменника: «Смотрицький, - пише М. Соловій, - належить до найкращих синів української церкви й народу, хоч поки що він є між тими недооцінюваними постатями, що, зазираючи своїм генієм у майбутність, стають незрозумілими для сучасности». На завершення А. Пекар відзначив ще позитивні сторони рецензованої праці, що значно «підносять її вартість»: а) автор помістив обширне резюме своєї монографії англійською мовою; б) подав численну бібліографію життя і діяльності М. Смотрицького та його епохи; в) склав покажчик імен і місцевостей, які зустрічаються в обох томах монографії. Водночас о. А. Пекар наголосив, що всі висновки й положення М. Соловія відкриті на подальшу дискусію, отож, слово за майбутніми дослідниками творчості Мелетія Смотрицького [11, с.230].

Наш огляд рецензій та відгуків на василіянську історіографію повоєнного періоду, які були опубліковані на сторінках україномовних наукових видань в діаспоpi, показує, що без їх врахування наше дослідження було б неповним. Адже вони значною мірою віддзеркалюють думки і погляди діаспорних науковців про доробок отців василіян у царині історико-церковних пошуків й публікацій і таким чином збагачують джерельну базу дослідження та полегшують з'ясування стану наукової розробки проблеми.

Інше важливе джерело для пізнання характеру василіянської історіографії другої половини XX ст. - це статті і розвідки про її окремих представників, де йдеться не тільки про життя, служіння і діяльність кожного з ченців ЧСВВ - науковців свого часу, але й подано оцінку їхнього наукового доробку. 


\section{REFERENCES}

1. Назарко I. Український історичний осередок в Римі // Український Історик. 1964. - P. 1. Ч. 4. - C. 18-20.

2. Назарко I. Український історичний осередок в Римі // Український Історик. 1964. - P. 1. Ч. 4. - С. 20.

3. Український Історик. - 1969. - Р. 6. - Ч. 1/3. - С. 166.

4. Український Історик. - 1969. - Р. 6. - Ч. 1/3. - С. 166-167.

5. Український Історик. - 1969. - Р. 6. - Ч. 1/3. - С. 167.

6. Український Історик. - 1972. - Р. 9. - Ч. 1/2. - С. 135-136.

7. Український Історик. - 1972. - Р. 9. - Ч. 1/2. - С. 135.

8. Український Історик. - 1972. - Р. 9. - Ч. 1/2. - С. 136.

9. Український Історик. - 1975. - Р. 12. - Ч. 3/4. - С. 128-130.

10. Український Історик. - 1981. - Р. 18. - Ч. 1/4. - С. 230-231.

11. Український Історик. - 1972. - Р. 9. - Ч. 1/2. - С. 230. 


\title{
THEMATIC ANALYSIS OF HISTORIOGRAPHIC WORKS ON ORDER ST. BASIL THE GREAT \\ (based on scientific publications of the Ukrainian diaspora of the second half of the 20th century)
}

\author{
Maryan Lozynskyi \\ Ivan Franko National University of Lviv, \\ Generala Chuprynky Str., 49, 79044, Lviv, Ukraine \\ e-mail: $\underline{\text { mlozynskyj@,lnu.edu.ua }}$
}

The author, as the researcher of the editions of the Order of St. Basil the Great Ukrainian Greek Catholic Church (and at the same time as the former long-time director of the Basilian Fathers' Publishing House «Missionary» since the beginning of Ukraine's independence) attracts attention to publications in the scientific literature, in particular, in the magazine "Ukrainian Historian», which was published since 1963 in the diaspora of the Ukrainian Historical Society.

The article uses the method of content analysis in relation to the scientific researches of the second half of the 20th century devoted to OSBM historiography. They open theological issues and historical aspects of the activities of church leaders in the Uniate Church (today the official name is the UGCC) for the readers of the scientific circle. The authors of these intelligence are also not well known to the general public by the OSBM monks who, after the Second World War, developed historical science and created a scientific periodical outside Ukraine, in particular, in Rome. These include, in particular, Fr. Atanasy Grigory The great, centenary anniversary of his birth is the scientific community of the LNU them. I. Franko together with the monks OSBM honored in November 2018. The Basilian Fathers in the countries of settlements, building up their religious life, tried to maintain a high level of book publishing and periodicals, as evidenced by the papers analyzed in the article.

The article covers the study of the historiography of OSBM during the 60-80s of the last century. At the same time, they are not limited to the aforementioned years and can become the object of scientific study by historians, theologians, religious scholars, journalists, because intelligence in the scientific literature on the periodicals and book publishing of the OSBM, the figures of the UGCC, open to these humanities new opportunities for understanding different periods of national and church history of Ukraine.

Key words: edition, magazine, «Ukrainian Historian», OSBM, research, monograph, review. 